2018-05-30

EIMS Fragmentation and MRM quantification of bacterial metabolites of the sea ice biomarker proxy IP25in

\title{
Arctic sediments.
}

Rontani, J-F

http://hdl.handle.net/10026.1/11086

10.1002/rcm.8101

Rapid Communications in Mass Spectrometry

Wiley

All content in PEARL is protected by copyright law. Author manuscripts are made available in accordance with publisher policies. Please cite only the published version using the details provided on the item record or document. In the absence of an open licence (e.g. Creative Commons), permissions for further reuse of content should be sought from the publisher or author. 


\section{EIMS Fragmentation and MRM quantification of bacterial metabolites of the sea ice biomarker proxy IP $_{25}$ in Arctic sediments}

Jean-François Rontani ${ }^{1 *}$, Claude Aubert ${ }^{2}$ and Simon T. Belt ${ }^{3}$

${ }^{1}$ Aix Marseille Univ, Université de Toulon, CNRS, IRD, MIO UM 110, Marseille, France, 13288, Marseille, France.

${ }^{2}$ Laboratoire de Pharmacocinétique et Toxicocinétique (EA 3286), Faculté de Pharmacie, 13385 Marseille, France.

${ }^{3}$ Biogeochemistry Research Centre, School of Geography, Earth and Environmental Sciences, University of Plymouth, Drake Circus, Plymouth, Devon PL4 8AA, UK.

* Corresponding author. Tel.: +33-4-86-09-06-02; fax: +33-4-91-82-96-41. E-mail address: jean-francois.rontani@mio.osupytheas.fr (J.-F. Rontani). 


\section{RATIONALE:}

3,9,13-trimethyl-6-(1,5-dimethylhexyl)-tetradecan-1,2-diol and 2,8,12-trimethyl-5-(1,5dimethylhexyl)-tridecanoic acid appear to be produced during the bacterial metabolism of $\mathrm{IP}_{25}$, a highly branched isoprenoid lipid often employed for past Arctic sea ice reconstruction. Characterization and quantification of these metabolites in sediments is essential to determine if bacterial degradation may exert a significant influence on $\mathrm{IP}_{25}$-based palaeo sea ice reconstructions.

\section{METHODS:}

EIMS fragmentation pathways of 3,9,13-trimethyl-6-(1,5-dimethylhexyl)-tetradecan-1,2-diol and 2,8,12-trimethyl-5-(1,5-dimethylhexyl)-tridecanoic acid TMS derivatives were investigated. These pathways were deduced by: (i) low energy CID-GC/MS/MS, (ii) accurate mass measurement and (iii) deuterium labelling.

\section{RESULTS:}

CID-MS/MS analyses, accurate mass measurement and deuterium labelling experiments enabled us to elucidate EIMS fragmentations of 3,9,13-trimethyl-6-(1,5-dimethylhexyl)tetradecan-1,2-diol and 2,8,12-trimethyl-5-(1,5-dimethylhexyl)-tridecanoic acid TMS derivatives. Some specific fragment ions useful in addition to chromatographic retention times for further characterization could be identified. As an application of some of the described fragmentations, TMS derivatives of these metabolites were characterized and quantified in MRM mode in different Arctic sediments.

\section{CONCLUSIONS:}

EIMS fragmentations of 3,9,13-trimethyl-6-(1,5-dimethylhexyl)-tetradecan-1,2-diol and 2,8,12-trimethyl-5-(1,5-dimethylhexyl)-tridecanoic acid TMS derivatives exhibit specific 
fragment ions, which appear to be very useful for the quantification of these bacterial metabolites of the palaeo tracer $\mathrm{IP}_{25}$ in sediments.

RUNNING TITLE: Mass fragmentation of $\mathrm{IP}_{25}$ bacterial metabolites

KEYWORDS: EIMS fragmentation; 2,8,12-trimethyl-5-(1,5-dimethylhexyl)-tridecanoic acid; 3,9,13-trimethyl-6-(1,5-dimethylhexyl)-tetradecan-1,2-diol; TMS derivatives; $\mathrm{IP}_{25}$; Bacterial metabolites. 
The reconstruction of sea ice conditions in the polar regions represents a key objective within palaeoceanography and palaeoclimatology. ${ }^{[1]}$ Performing such reconstructions requires the use of so-called proxies and, notably, of molecular biomarkers of ice algae. ${ }^{[2]}$ Among these, the $\mathrm{C}_{25}$ highly branched isoprenoid alkene $\mathrm{IP}_{25}$ (3,9,13-trimethyl-6-(1,5-dimethylhexyl)-tetradec-1ene) (1) (Scheme 1) produced selectively by certain sea ice diatoms ${ }^{[3]}$ has become a wellestablished proxy for palaeo sea ice reconstruction in the Arctic ${ }^{[4]}$ and appears relatively stable in the recent and long-term sedimentary record ${ }^{[5-7]}$. However, the extent to which $\mathrm{IP}_{25}$ distributions may be significantly altered by degradative processes in sediments has remained a largely unexplored research question.

Recently, we showed that $\mathrm{IP}_{25}$ may indeed be susceptible to autoxidative degradation processes in near-surface oxic sediments. ${ }^{[8]}$ As part of this previous study, two bacterial metabolites of $\mathrm{IP}_{25}$ : 3,9,13-trimethyl-6-(1,5-dimethylhexyl)-tetradecan-1,2-diol (2) and 2,8,12trimethyl-5-(1,5-dimethylhexyl)-tridecanoic acid (3), produced under oxic and anoxic conditions (Scheme 1), were also detected.

In the present work, we aimed to: (i) elucidate the electron ionization (EI) fragmentation pathways of trimethylsilyl (TMS) derivative of diol $\mathbf{2}$ and acid $\mathbf{3}$ by using low-energy collisioninduced dissociation (CID) GC/MS/MS, isotopic labelling and accurate mass measurements and (ii) quantify these compounds in different Arctic sediment samples in multiple reaction monitoring (MRM) mode using transitions based on the main fragmentation pathways elucidated.

\section{EXPERIMENTAL}

\section{Chemicals}


Unlabelled and perdeuterated (99.0 atom\% D) N,O-bis(trimethysilyl) trifluoroacetamide (BSTFA) were obtained from Supelco (St. Quentin Fallavier, France) and Campro Scientific (Veenendaal, The Netherlands), respectively.

A sample of $\mathrm{IP}_{25}$ (ca. 99\%) was obtained by extraction of a multi-kg quantity of sediment from Barrow Strait in the Canadian Arctic (Station 4) and purification by a combination of open column chromatography $\left(\mathrm{SiO}_{2}\right.$; hexane) and Ag-ion HPLC as described previously in detail by Belt et al. ${ }^{[9]}$.

$\mathrm{OsO}_{4}$ oxidation of $\mathrm{IP}_{25}(\mathbf{1})$ in anhydrous dioxane/pyridine afforded 3,9,13-trimethyl-6(1,5-dimethylhexyl)-tetradecan-1,2-diol (2). ${ }^{[8]}$ Treatment of this diol with lead tetraacetate in refluxing toluene ${ }^{[10]}$ and subsequent oxidation of the foregoing aldehyde with $\mathrm{AgNO}_{3} / \mathrm{NaOH}^{[11]}$ yielded 2,8,12-trimethyl-5-(1,5-dimethylhexyl)-tridecanoic acid (3).

Due to the very low amounts of $\mathrm{IP}_{25}$ available, compounds $\mathbf{2}$ and $\mathbf{3}$ could not be produced in sufficient amounts to permit quantification, although comparison of their mass fragmentations and retention times with compounds detected in sediments allowed their unambiguous identification. Quantification was thus carried out with standards of two highly structurally related compounds. Diol 2 was quantified using an external standard of 3,7,11,15tetramethylhexadecan-1,2-diol (4) produced by $\mathrm{Pd} / \mathrm{CaCO}_{3}$-catalysed hydrogenation of 3methylidene-7,11,15-trimethylhexadecan-1,2-diol (5) whose synthesis was described previously, ${ }^{[12]}$ while quantification of acid $\mathbf{3}$ was carried out with 2,6,10,14tetramethylpentadecanoic acid (pristanic acid) (6) (Sigma Aldrich, St. Quentin Fallavier, France).

\section{Sampling and treatment of sediments}

Sampling locations correspond to Barrow Strait (Station 4, $74^{\circ} 16^{\prime} 12^{\prime \prime} \mathrm{N}, 31^{\circ} 46^{\prime} 12^{\prime \prime} \mathrm{W}$ ) and Viscount Melville Sound (Station 308, $74^{\circ} 7^{\prime} 43^{\prime \prime} \mathrm{N}, 103^{\circ} 4^{\prime} 12^{\prime \prime} \mathrm{W}$ ) in the Canadian Arctic. In each case, box cores were collected, sectioned on board, with sub-samples (1-cm resolution) then 
being freeze-dried before storage $\left(<4^{\circ} \mathrm{C}\right)$ prior to analysis. Sediment sub-samples from sectioned box cores were placed in methanol $(\mathrm{MeOH})(15 \mathrm{~mL})$ and hydroperoxides were reduced to the corresponding alcohols with excess $\mathrm{NaBH}_{4}\left(70 \mathrm{mg}, 30 \mathrm{~min}\right.$ at $\left.20^{\circ} \mathrm{C}\right)$. Following the reduction step, water $(15 \mathrm{~mL})$ and $\mathrm{KOH}(1.7 \mathrm{~g})$ were added and the mixture saponified by refluxing $(2 \mathrm{~h})$. After cooling, the contents of the flask were acidified $(\mathrm{HCl}$, to $\mathrm{pH} 1)$ and extracted three times with dichloromethane (DCM) $(30 \mathrm{~mL})$. The combined DCM extracts were dried over anhydrous $\mathrm{Na}_{2} \mathrm{SO}_{4}$, filtered and concentrated to give the total lipid extract (TLE). Since $\mathrm{IP}_{25}$ oxidation product content was quite low relative to other lipids, accurate quantification required further separation of the TLE using column chromatography (silica; Kieselgel $60,8 \times 0.5 \mathrm{~cm}) . \mathrm{IP}_{25}$ was obtained by elution with hexane $(10 \mathrm{~mL})$ and its oxidation products by subsequent elution with DCM $(10 \mathrm{~mL})$ and $\mathrm{MeOH}(10 \mathrm{~mL})$.

\section{Silylation}

DCM and MeOH eluates (evaporated to dryness) and standards were derivatized by dissolving them in $300 \mu \mathrm{L}$ pyridine/bis-(trimethylsilyl)trifluoroacetamide (BSTFA; Supelco; $2: 1, \mathrm{v} / \mathrm{v}$ ) and silylated $\left(50^{\circ} \mathrm{C}, 1 \mathrm{~h}\right)$. After evaporation to dryness under a stream of $\mathrm{N}_{2}$, the derivatized residue was dissolved in hexane/BSTFA (to avoid desilylation) and analysed by mass spectrometric methods.

\section{Gas chromatography/electron ionization tandem mass spectrometry}

GC/EIMS and GC/EIMS/MS experiments were performed using an Agilent 7890A/7000A tandem quadrupole gas chromatograph system (Agilent Technologies, Parc Technopolis - ZA Courtaboeuf, Les Ulis, France). A cross-linked 5\% phenyl-methylpolysiloxane (Agilent; HP5MS) $(30 \mathrm{~m} \times 0.25 \mathrm{~mm}, 0.25 \mu \mathrm{m}$ film thickness $)$ capillary column was employed. Analyses were performed with an injector operating in pulsed splitless mode set at $270^{\circ} \mathrm{C}$ and the oven 
temperature programmed from $70^{\circ} \mathrm{C}$ to $130^{\circ} \mathrm{C}$ at $20^{\circ} \mathrm{C} \mathrm{min}^{-1}$, then to $250^{\circ} \mathrm{C}$ at $5^{\circ} \mathrm{C} \mathrm{min}^{-1}$ and then to $300^{\circ} \mathrm{C}$ at $3{ }^{\circ} \mathrm{C} \mathrm{min}^{-1}$. The pressure of the carrier gas (He) was maintained at $0.69 \times 10^{5}$ Pa until the end of the temperature program and then programmed from $0.69 \times 10^{5} \mathrm{~Pa}$ to $1.49 \mathrm{x}$ $10^{5} \mathrm{~Pa}$ at $0.04 \times 10^{5} \mathrm{~Pa} \mathrm{~min}^{-1}$. The following mass spectrometric conditions were employed: electron energy, $70 \mathrm{eV}$; transfer line, $300^{\circ} \mathrm{C}$; source temperature, $230^{\circ} \mathrm{C}$; quadrupole 1 temperature, $150^{\circ} \mathrm{C}$; quadrupole 2 temperature, $150^{\circ} \mathrm{C}$; collision gas $\left(\mathrm{N}_{2}\right)$ flow, $1.5 \mathrm{~mL} \mathrm{~min}{ }^{-1}$; quench gas (He) flow, $2.25 \mathrm{~mL} \mathrm{~min}^{-1}$; mass range, 50-700 Dalton; cycle time, $313 \mathrm{~ms}$. Collision induced dissociation (CID) was optimized by using collision energies at 5, 10, 15 and $20 \mathrm{eV}$. Quantification of diol $\mathbf{2}$ and acid $\mathbf{3}$ was carried out with external standards in multiple reaction monitoring (MRM) mode. Precursor ions were selected from the more intense ions observed in EI mass spectra.

\section{Gas chromatography/electron ionization quadrupole time of flight mass spectrometry}

Accurate mass measurements were carried out in full scan mode with an Agilent 7890B/7200 GC/QTOF System (Agilent Technologies, Parc Technopolis - ZA Courtaboeuf, Les Ulis, France). A cross-linked 5\% phenyl-methylpolysiloxane (Agilent; HP-5MS ultra inert) (30 m × $0.25 \mathrm{~mm}, 0.25 \mu \mathrm{m}$ film thickness) capillary column was employed. Analyses were performed with an injector operating in pulsed splitless mode set at $270^{\circ} \mathrm{C}$ and the oven temperature programmed from $70^{\circ} \mathrm{C}$ to $130^{\circ} \mathrm{C}$ at $20^{\circ} \mathrm{C} \mathrm{min}^{-1}$ and then to $300^{\circ} \mathrm{C}$ at $5^{\circ} \mathrm{C} \mathrm{min}^{-1}$. The pressure of the carrier gas $(\mathrm{He})$ was maintained at $0.69 \times 10^{5} \mathrm{~Pa}$ until the end of the temperature program. Instrument temperatures were $300^{\circ} \mathrm{C}$ for transfer line and $230^{\circ} \mathrm{C}$ for the ion source. Nitrogen $\left(1.5 \mathrm{~mL} \mathrm{~min}^{-1}\right)$ was used as collision gas. Accurate mass spectra were recorded across the range $m / z$ 50-700 at $4 \mathrm{GHz}$. The QTOF-MS instrument provided a typical resolution ranging from 8009 to 12252 from $\mathrm{m} / z$ 68.9955 to 501.9706. Perfluorotributylamine (PFTBA) was utilized for daily MS calibration. 


\section{RESULTS AND DISCUSSION}

EIMS fragmentations of 3,9,13-trimethyl-6-(1,5-dimethylhexyl)-tetradecan-1,2-diol (2) TMS ether derivative

As expected, the EI mass spectrum of the TMS derivative of compound $\mathbf{2}$ exhibits intense ions $\mathbf{a}^{+}$and $\mathbf{b}^{+}$at $m / z, 425$ and $m / z, 103$, respectively (Fig. 1A) resulting from cleavage between the two carbon atoms bearing the TMS ether groups (Scheme 2). It also shows less specific $\mathrm{C}_{\mathrm{n}} \mathrm{H}_{2 \mathrm{n}+1}{ }^{+}$and $\mathrm{C}_{\mathrm{n}} \mathrm{H}_{2 \mathrm{n}-1}{ }^{+}$ion series typical of branched carbon chains, ${ }^{[13]}$ while fragment ions at $\mathrm{m} / \mathrm{z} 147$ and $\mathrm{m} / \mathrm{z} 205$ are characteristic of interactions between the two silylated functionalities ${ }^{[14]}$ Since one of the aims of this current study was to develop a MRM method to permit quantification of compound $\mathbf{2}$, we therefore focused on the fragmentation of the specific ion $\mathbf{a}^{+}$. Among the numerous product ions resulting from CID analysis of this ion (Table 1), ions $\mathbf{c}^{+}$at $m / z, 335$ and $\mathbf{d}^{+\bullet}$ at $m / z, 334$ appeared to be the most specific. In order to explain the formation of these ions we propose the fragmentation pathways described in Scheme 2. The loss of a neutral molecule of trimethylsilanol by the ion $\mathbf{a}^{+}$, which is at the origin of the formation of ion $\mathbf{c}^{+}$, could be initiated by hydride transfer from the tertiary carbon-7 to carbon23 via a six-membered transition state and subsequent cyclisation (Scheme 2). This hypothesis is well supported by the complete absence of such a process during CID analysis of ion $\mathbf{e}^{+}$at $m / z$ 355, which results from cleavage between the two ether groups of the 3,7,11,15tetramethylhexadecan-1,2-diol TMS derivative (Table 1, Fig. 4). Subsequent loss of a hydrogen atom by ion $\mathbf{c}^{+}$affords the monounsaturated ion $\mathbf{d}^{+\bullet}$ at $\mathrm{m} / \mathrm{z} 334$ (Scheme 2). CID analyses confirmed that ion $\mathbf{c}^{+}$is the source of ion $\mathbf{d}^{+\bullet}$ (Table 1) and the structures of these ions were further verified by accurate mass measurement (Table 2).

EIMS fragmentations of 2,8,12-trimethyl-5-(1,5-dimethylhexyl)-tridecanoic acid (3) TMS ester derivative 
Peaks at $\mathrm{m} / \mathrm{z} 440$ (molecular ion $\mathbf{f}^{+\bullet}$ ) and $\mathrm{m} / \mathrm{z} 425\left(\mathbf{g}^{+}\right)$resulting from the classical loss of a methyl radical from the ionized TMS group are present in weak abundance in the EI mass spectrum of the TMS derivative of compound $\mathbf{3}$ (Fig. 1B). This spectrum is strongly dominated by a peak at $\mathrm{m} / \mathrm{z} 146$ corresponding to classical $\gamma$-hydrogen rearrangement of the ionized carboxylic ester group (MacLafferty cleavage with charge retention ${ }^{[13]}\left(\right.$ ion $\left.\mathbf{h}^{+\bullet}\right)$ ) (Scheme 3). Subsequent loss of a methyl radical by the TMS group of this ion $\mathbf{h}^{+\bullet}$ affords ion $\mathbf{i}^{+}$at $\mathrm{m} / \mathrm{z} 131$, while $\delta$-hydrogen rearrangement of the ionized ester group ${ }^{[13]}$ yields ion $\mathbf{j}^{+}$at $\mathrm{m} / \mathrm{z} 159$. Two other significant peaks at $\mathrm{m} / z, 130$ and 143 (ions $\mathbf{~ k}^{+\bullet}$ and $\mathbf{l}^{+}$) are also noted (Fig. 1B) and are attributed to the loss of a neutral molecule of methane from ions $\mathbf{h}^{+\bullet}$ and $\mathbf{j}^{+}$, respectively. Indeed, the loss of methane is often observed in the EI mass spectra of trimethylsilyl derivatives. ${ }^{[14-16]}$ Examination of the mass spectrum of the perdeuterated TMS derivative of the acid $\mathbf{3}$ (Fig. 1C) showed unambiguously that there is a contribution of only three hydrogen atoms of the silyl group to the neutral methane molecule (i.e. a shift of ions $\mathbf{I}^{+}$and $\mathbf{k}^{+\bullet}$ by $6 \mathrm{~m} / z$ units). To rationalise the formation of ion $\mathbf{l}^{+}(\mathrm{m} / \mathrm{z}, 143)$ from ion $\mathbf{j}^{+}(\mathrm{m} / \mathrm{z}, 159)$, we thus propose a fragmentation mechanism involving the concerted loss of a silyl methyl group and of the hydrogen atom which originally migrated from the $\delta$-position to the carbonyl group ${ }^{[13]}$ (Scheme 3), as previously proposed by Tulloch ${ }^{[17]}$ in the case of linear TMS esters. In contrast, in the case of ion $\mathbf{h}^{+\bullet}(\mathrm{m} / \mathrm{z}, 146)$, another fragmentation mechanism involving the loss of a silyl methyl group and of one hydrogen atom from the allylic carbon-3, and resulting in the formation of the cyclic ion $\mathbf{k}^{+\bullet}(\mathrm{m} / \mathrm{z}, 130)$ was proposed (Scheme 3$)$. The participation of a hydrogen atom from carbon-3 is further supported by the absence of an ion corresponding to the loss of methane by ion $\mathbf{h}^{+\bullet}$ in the case of linear TMS esters. ${ }^{[17]}$ CID analyses also confirmed that ions $\mathbf{h}^{\mathbf{t}^{\bullet}}$ and $\mathbf{j}^{\mathbf{+}}$ are the sources of ions $\mathbf{k}^{+\bullet}$ and $\mathbf{I}^{+}$, respectively (Table 1). Two interesting additional peaks at $\mathrm{m} / \mathrm{z}$ 327 and 237 could be also observed in the EI mass spectrum of the TMS derivative of compound 3 (Fig. 1B). The fragment ion $\mathbf{m}^{+}$at $m / z 327$ corresponds to the loss of the 1,5-dimethylhexyl 
chain by the ionized molecule (Fig. 1B). The structure of ion $\mathbf{m}^{+}$was confirmed by accurate mass measurement (GC-QTOF) (Table 2) and is further verified by the shift of this ion by 9 $m / z$ units in the EI mass spectrum of the perdeuterated TMS derivative of acid $\mathbf{3}$ (Fig. 1C). As confirmed by CID analyses of ion $\mathbf{m}^{+}$(Table 1), the formation of ion $\mathbf{n}^{+}$at $m / z 237$ results from the loss of a neutral molecule of TMSOH from ion $\mathbf{m}^{+}$.

The accurate masses of ions h-n (charges not shown) showed only minor deviations (ranging from 1.9 to $9.1 \mathrm{ppm}$ ) from the calculated masses (Table 2), thus confirming the elemental composition of the fragment ions in each case.

Interestingly, the abundance of ions $\mathbf{k}^{+\bullet}$ and $\mathbf{l}^{+}$appeared to be considerably higher in the TOF mass spectrum of the TMS derivative of compound 3 reported previously ${ }^{[8]}$ compared to $^{2}$ that in its EI mass spectrum (Fig. 1B). We attribute this difference to the collision of parent ions $\mathbf{h}^{\mathbf{+}^{\bullet}}$ and $\mathbf{j}^{+}$with nitrogen (TOF analyses carried out with collision gas opened), which may favour the loss of neutral methane. This conclusion is supported by the production of ion $\mathbf{k}^{+\bullet}$ during CID analysis of ion $\mathbf{h}^{+\bullet}$ carried out with a collision energy of $0 \mathrm{eV}$ (Table 1).

\section{MRM quantification of compounds 2 and 3 in sediment samples}

The fragmentation pathways described in the previous sections were employed together with retention times to identify and quantify compounds $\mathbf{2}$ and $\mathbf{3}$ in the DCM- and MeOH-eluted fractions of TLE of several Arctic sediment samples, respectively. Specifically, the mass spectral transitions $m / z 425 \rightarrow 335, m / z 425 \rightarrow 334$ and $m / z$, $425 \rightarrow 111$ were employed in the case of diol 2 , while the transitions $\mathrm{m} / \mathrm{z} 146 \rightarrow 130, \mathrm{~m} / \mathrm{z}, 146 \rightarrow 131, \mathrm{~m} / \mathrm{z} 159 \rightarrow 143$ and $\mathrm{m} / \mathrm{z}$ $327 \rightarrow 237$ were used for acid $\mathbf{3}$ (Figs. 2 and 3). The presence of only one pair of enantiomers of the diol 2 in sediments (Fig. 2) further supports its enzymatic production. As described in the Experimental section, quantification of $\mathbf{2}$ and $\mathbf{3}$ involved the use of TMS derivatives of structurally similar compounds as external standards. Diol 2 was quantified with the 3,7,11,15- 
tetramethylhexadecan-1,2-diol (4) TMS derivative. The transitions employed for quantification were $m / z 425 \rightarrow 111$ for diol 2 and $m / z 355 \rightarrow 111$ for the external standard 4 . A correction factor that took into account the proportion of the selected precursor ion $\left(\mathbf{a}^{+}\right.$at $m / z 425$ or $\mathbf{e}^{+}$at $m / z$ 355) in the EIMS of each compound (Figs. 1A and 4A) and that of the selected MRM transition in each CID-MS (Table 1) was employed. Similarly, acid 3 was quantified with a standard of the TMS derivative of pristanic acid (5), which exhibits a very similar EI mass spectrum to acid 3 (Fig. 4B) and exactly the same $m / z \quad 146 \rightarrow 130$ transition. The limits of detection (10 pg for the diol 2 and 40 pg for the acid 3 ) were determined according to a signalto-noise ratio greater than 5 . The linear range was determined using values that met the standard analysis criteria of less than $15 \%$ deviation across the concentration range. Linear responses were obtained over 2 to 3 orders of magnitude. The results of this quantification are summarized in Table 3 and Fig. 5. The very low concentrations of diol 2 detected in sediments likely reflect its rapid enzymatic conversion to acid $\mathbf{3}$, especially as concentrations of the latter are much higher than the former. The proportion of acid $\mathbf{3}$ relative to the parent lipid $\mathrm{IP}_{25}$ clearly appeared to be highest in the oxic zone of sediments, suggesting that bacterial degradation of this biomarker in Arctic sediments is mainly driven by aerobic bacteria (Scheme 1). As suggested previously, ${ }^{[8]}$ the susceptibility of $\mathrm{IP}_{25}$ towards biotic and abiotic degradation seems thus to be especially prevalent in cases where sequestered ice algal material experiences long residence times in the oxic layer of sediments. Further, the apparent good preservation of acid $\mathbf{3}$ in anoxic sediments (Fig. 5A) supports the use of this metabolite as a tracer of $\mathrm{IP}_{25}$ bacterial degradation in overlying and relatively shallow oxic sedimentary environments.

\section{Conclusions}

A combination of CID-MS/MS, deuterium labelling and accurate mass measurements was employed to elucidate EI mass fragmentations of the TMS derivatives of 3,9,13-trimethyl-6- 
(1,5-dimethylhexyl)-tetradecan-1,2-diol (2) and 2,8,12-trimethyl-5-(1,5-dimethylhexyl)tridecanoic acid (3): bacterial metabolites of the Arctic sea ice proxy $\mathrm{IP}_{25}$. On the basis of these fragmentations, some MRM transitions were selected and applied to lipid extracts of several Arctic sediment samples. These transitions appear to be very useful in identifying and quantifying relatively low amounts of these bacterial metabolites in natural samples. While anaerobic biodegradation of $\mathrm{IP}_{25}$ in anoxic sediments cannot be totally excluded, the results obtained here strongly suggest that its biodegradation is mainly driven by aerobic bacteria in the oxic layers of Arctic sediments.

\section{Acknowledgements}

Financial support from the Centre National de la Recherche Scientifique (CNRS) and the AixMarseille University is gratefully acknowledged. Thanks are due to the FEDER OCEANOMED ( $\mathrm{N}^{\circ}$ 1166-39417) for the funding of the apparatus employed. We are grateful to L. Vare, G. Massé, A. Rochon and the officers and crew of the CCGS Amundsen for help with obtaining box core sediment material.

References

[1] Stein R, Fahl K, Schade I, et al. Holocene variability in sea ice cover, primary production, and Pacific-Water inflow and climate change in the Chukchi and East Siberian Seas (Arctic Ocean). J Quat Sci 2017; 32: 362-379.

[2] Belt ST, Brown TA, Ringrose AE et al. Quantitative measurements of the sea ice diatom biomarker $\mathrm{IP}_{25}$ and sterols in Arctic sea ice and underlying sediments: Further considerations for palaeo sea ice reconstruction. Org Geochem 2013; 62: 33-45. 
[3] Brown TA, Belt ST, Tatarek A, Mundy CJ. Source identification of the Arctic sea ice proxy IP25. Nature Commun 2014; 5: 4197.

[4] Belt ST, Müller J. The Arctic sea ice biomarker $\mathrm{IP}_{25}$ : a review of current understanding, recommendations for future research and applications in palaeo sea ice reconstructions. Quat Sci Rev 2013; 79: 9-25.

[5] Knies J, Cabedo-Sanz P, Belt ST, Baranwal S, Fietz S, Rosell-Melé A. The emergence of modern sea ice cover in the Arctic Ocean. Nature Commun 2014; 5: 5608.

[6] Stoynova V, Shanahan TM, Hughen KA, de Vernal A. Insights into circum-Arctic sea ice variability from molecular geochemistry. Quat Sci Rev 2013; 79: 63-73.

[7] Müller J, Wagner A, Fahl K, Stein R, Prange M, Lohmann G. Towards quantitative sea ice reconstructions in the northern North Atlantic: A combined biomarker and numerical modelling approach. Earth Planet Sci Lett 2011; 306: 137-148.

[8] Rontani J-F, Belt ST, Amiraux R. Biotic and abiotic degradation of the sea ice diatom biomarker $\mathrm{IP}_{25}$ and selected algal sterols in near-surface Arctic sediments. Org Geochem 2018; 118: 73-88.

[9] Belt ST, Brown TA, Navarro-Rodriguez A, Cabedo-Sanz P, Tonkin A, Ingle R. A reproducible method for the extraction, identification and quantification of the Arctic sea ice proxy $\mathrm{IP}_{25}$ from marine sediments. Anal Met 2012; 4: 705-713.

[10] Wade LG. Organic Chemistry. 6th ed. New Jersey, Prentice Hall; 2005.

[11] Hassner A, Stumer C. Organic Syntheses Based on Name Reactions and Unnamed Reactions, Oxford, Elsevier Science Ltd; 1994.

[12] Rontani J-F, Aubert C. Characterization of isomeric allylic diols resulting from chlorophyll phytyl side-chain photo- et autoxidation by EI gas chromatography/mass spectrometry. Rapid Commun Mass Spectrom 2005; 19: 1-11. 
[13] McLafferty FW, Tureček F. Interpretation of Mass Spectra. 4th ed. Sausalito, California, University Science Books; 1993.

[14] Rontani J-F, Aubert C. Hydrogen and trimethylsilyl transfers during EI mass spectral fragmentation of hydroxycarboxylic and oxocarboxylic acid trimethylsilyl derivatives. $J$ Am Soc Mass Spectrom 2008; 19: 66-75.

[15] Spirau F, Bourgeois G, Dunoguès J. Gas chromatography/mass spectrometry for the study of the polysilylation of 1-bromonaphtalene. Detection of new polysilylated products. Rapid Commun Mass Spectrom 1998; 12: 1419-1424.

[16] Leblanc D, Audier HE., Denhez JP. Reaction of silyl cations with ketones in the gas phase. J Mass Spectrom 1999; 34: 969-974.

[17] Tulloch AP. Mass spectra of TMS esters of deuterated decanoic acids and of TMS ethers of deuterated decanols. Lipids 1985; 20: 404-411. 


\section{Figure and scheme captions}

Figure 1. EI mass spectra of diol 2 TMS derivative (A) and acid 3 TMS (A) and perdeuterated TMS (C) derivatives.

Figure 2. MRM chromatograms $(\mathrm{m} / \mathrm{z} 425 \rightarrow 111, \mathrm{~m} / \mathrm{z} 425 \rightarrow 334$ and $\mathrm{m} / \mathrm{z} 425 \rightarrow 335)$ of silylated standard diol 2 (A) and DCM fraction obtained from the 4-5 $\mathrm{cm}$ layer of the core sediment from Barrow Strait (STN 4) (B).

Figure 3. MRM chromatograms $(m / z, 146 \rightarrow 130, m / z, 146 \rightarrow 131, m / z, 159 \rightarrow 143$ and $m / z, 327$ $\rightarrow 237$ ) of silylated standard acid 3 (A) and $\mathrm{MeOH}$ fractions obtained from the 2-3 cm layer of the core sediment from Barrow Strait (STN 4) (B) and Viscount Melville Sound (STN 308) (C).

Figure 4. EI mass spectra of 3,7,11,15-tetramethylhexadecan-1,2-diol (4) (A) and pristanic acid (5) (B) TMS derivatives used as standards.

Figure 5. Downcore plots of the concentrations of $\operatorname{IP}_{25}(\mathbf{0})$ and acid $3(\square)$ in sediments from the two stations investigated. (The dashed lines represent the redox boundaries).

Scheme 1. Proposed mechanisms for the aerobic and anaerobic bacterial degradation of $\mathrm{IP}_{25}$. (* Note we use the IUPAC nommenclature in this paper, which contrasts with carbon numbering often used for $\mathrm{IP}_{25}$ and other HBIs in the literature based on the structure of the parent saturated $\mathrm{C}_{25}$ alkane. 
Scheme 2. Proposed fragmentation mechanisms of diol 2 TMS derivative.

Scheme 3. Proposed fragmentation mechanisms of acid $\mathbf{3}$ TMS derivative. 
$\times 10^{2}$

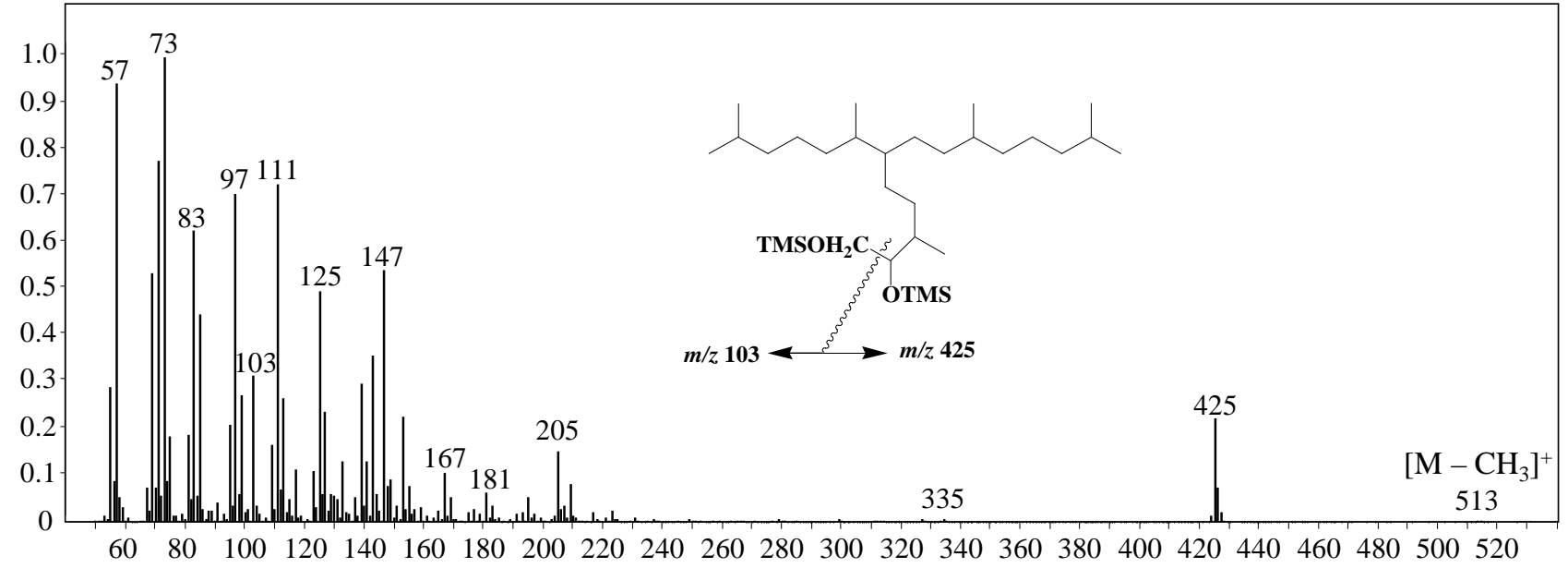

B $(\mathrm{m} / \mathrm{z})$
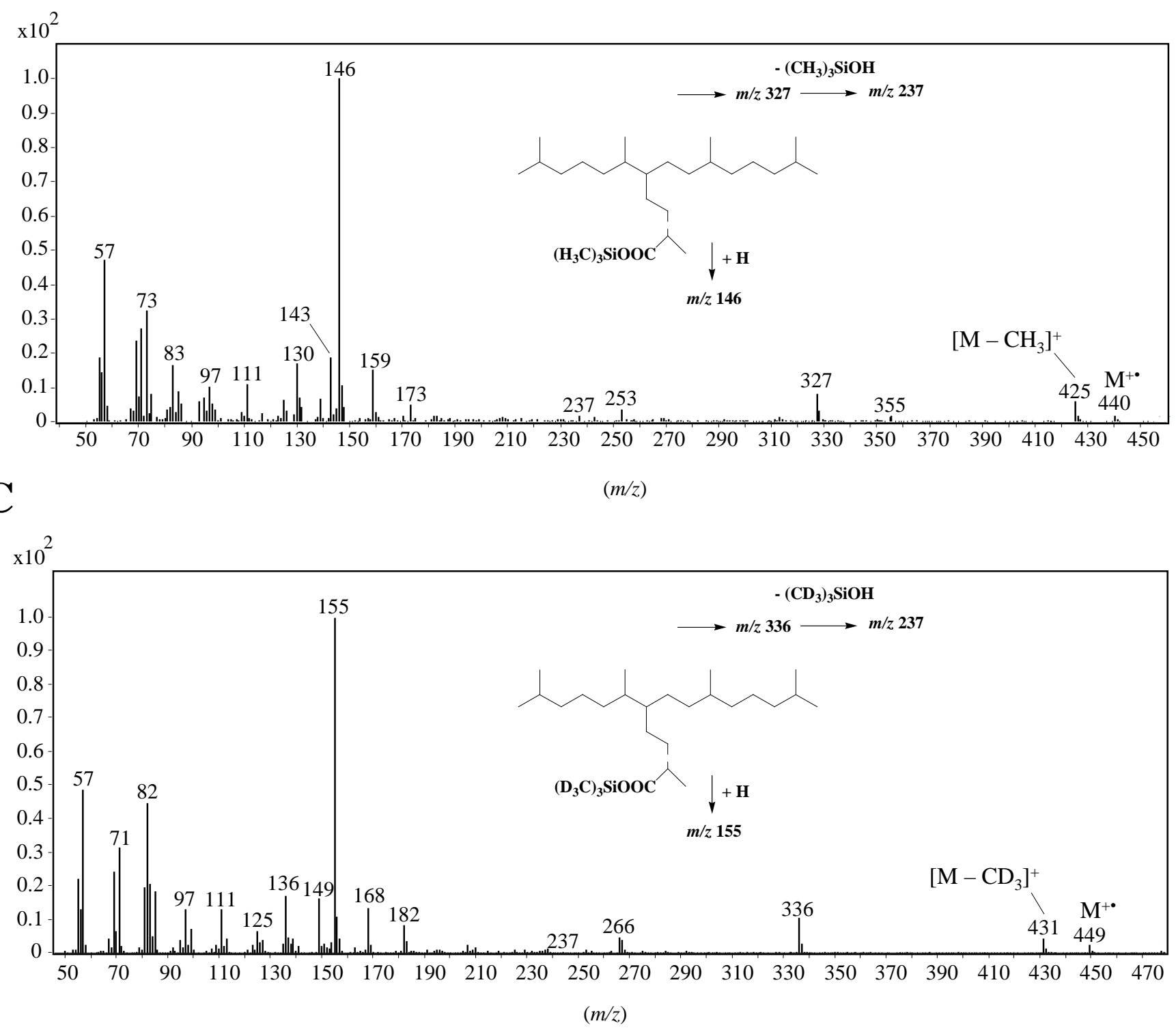


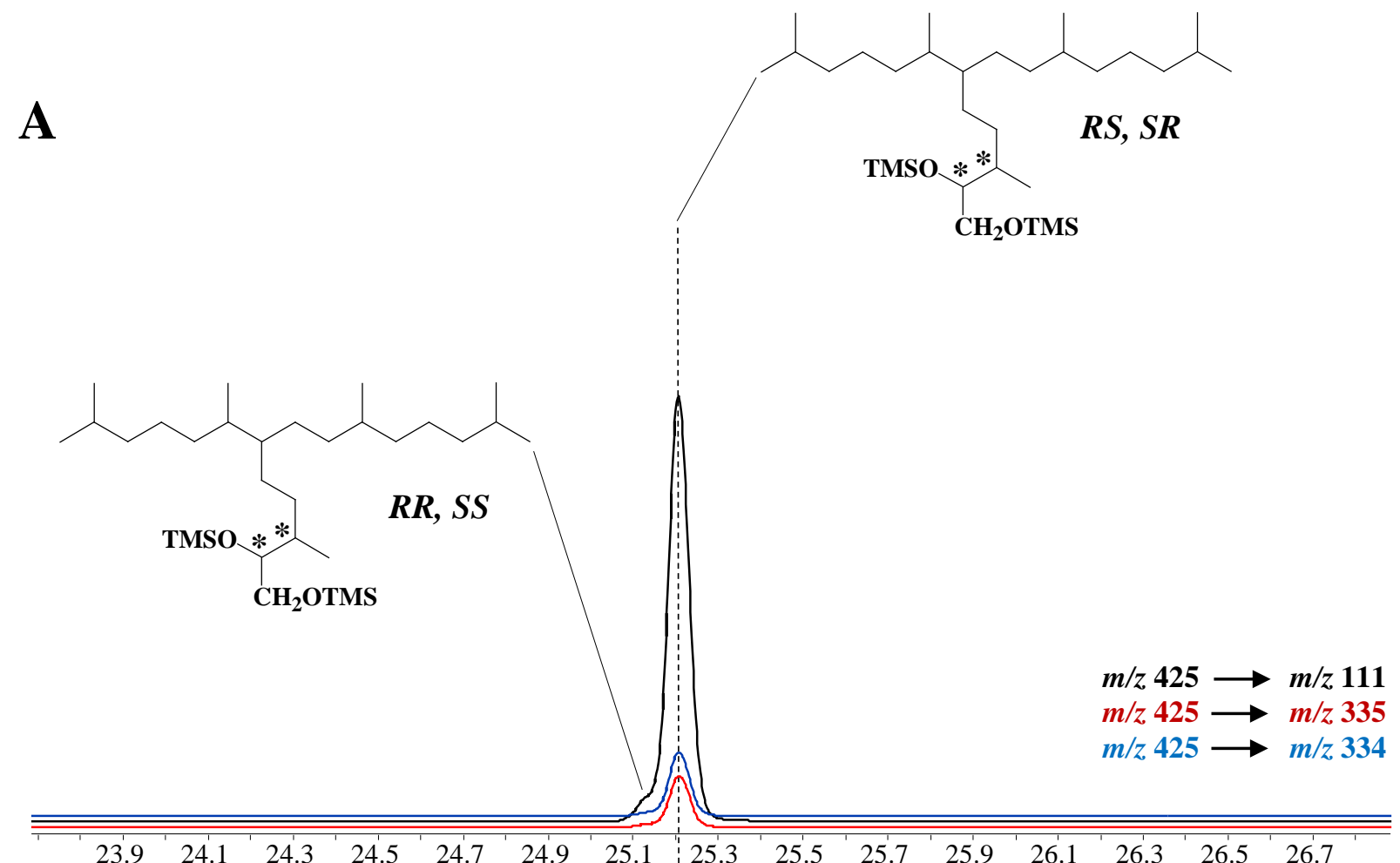

\section{B}

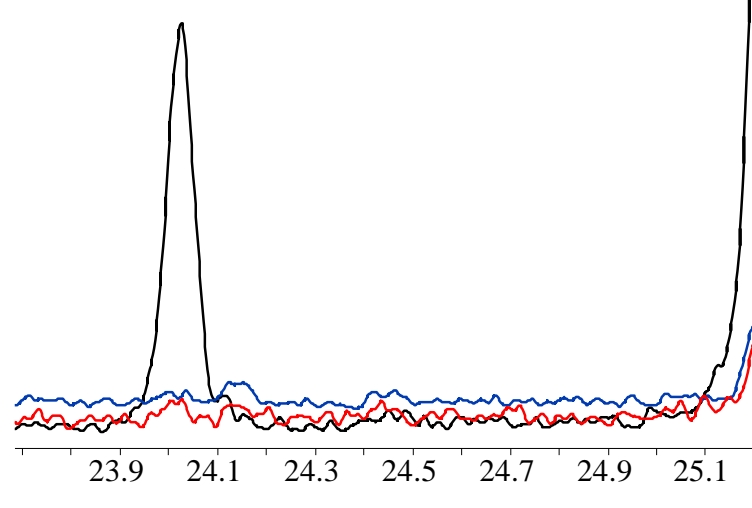

$\mathrm{m} / \mathrm{z} 425 \longrightarrow \mathrm{m} / \mathrm{z} 111$

$\mathrm{m} / \mathrm{z} 425 \longrightarrow \mathrm{m} / \mathrm{z} 335$

$\mathrm{m} / \mathrm{z} 425 \longrightarrow \mathrm{m} / \mathrm{z} 334$

Retention time (min) 


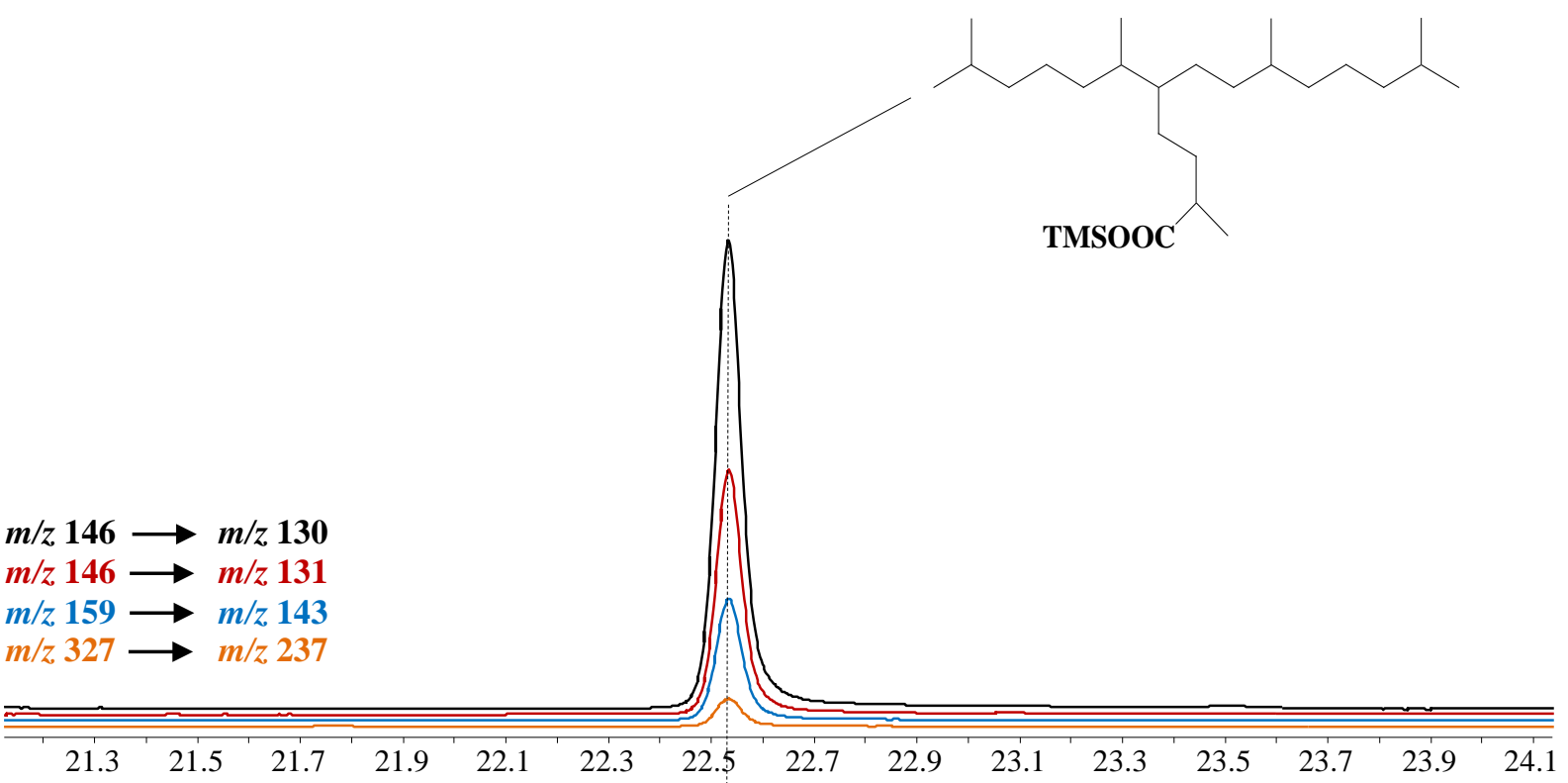

B

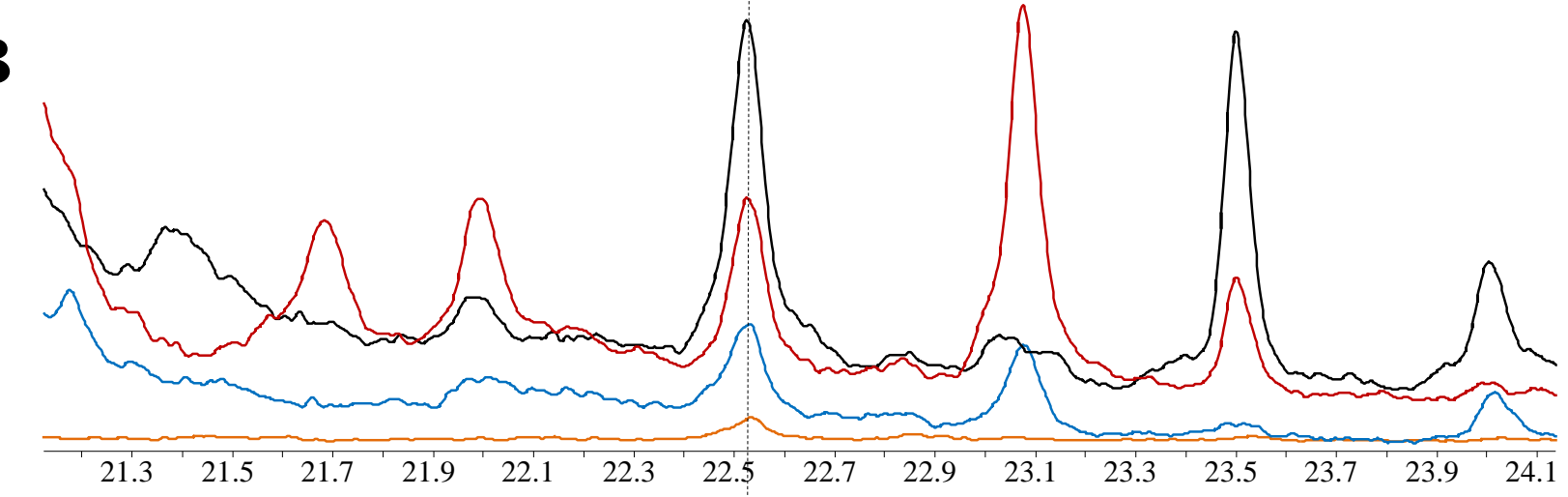

C

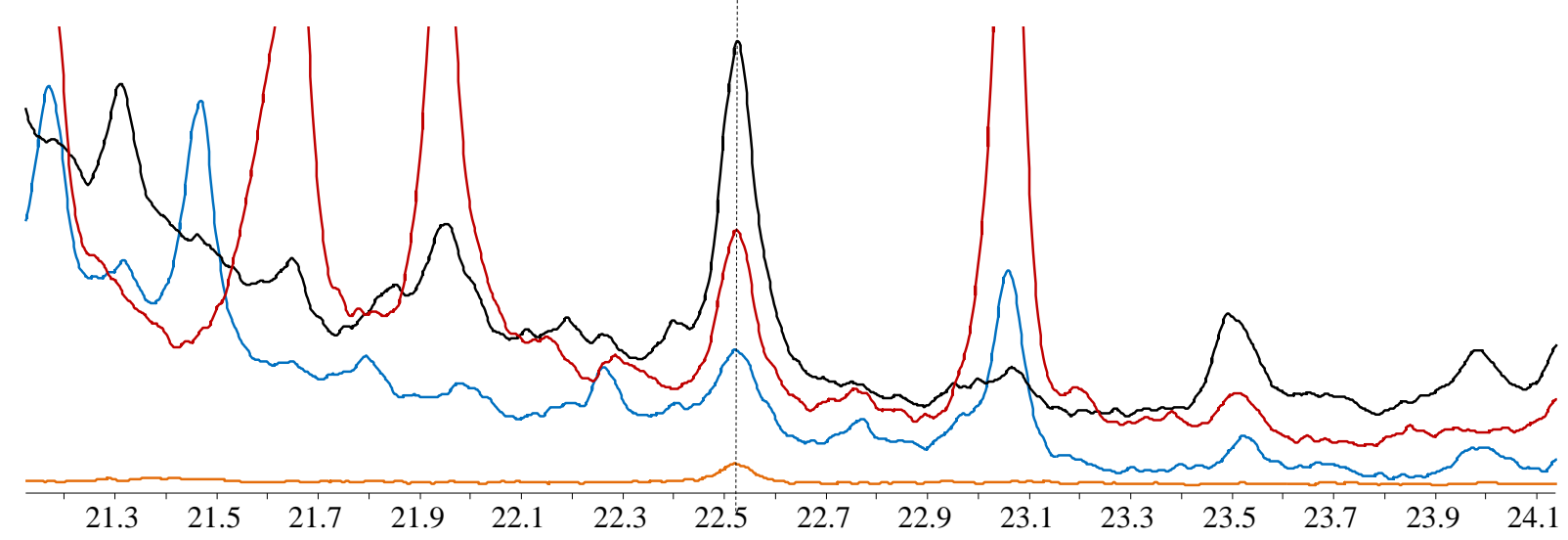

Retention time (min) 
A

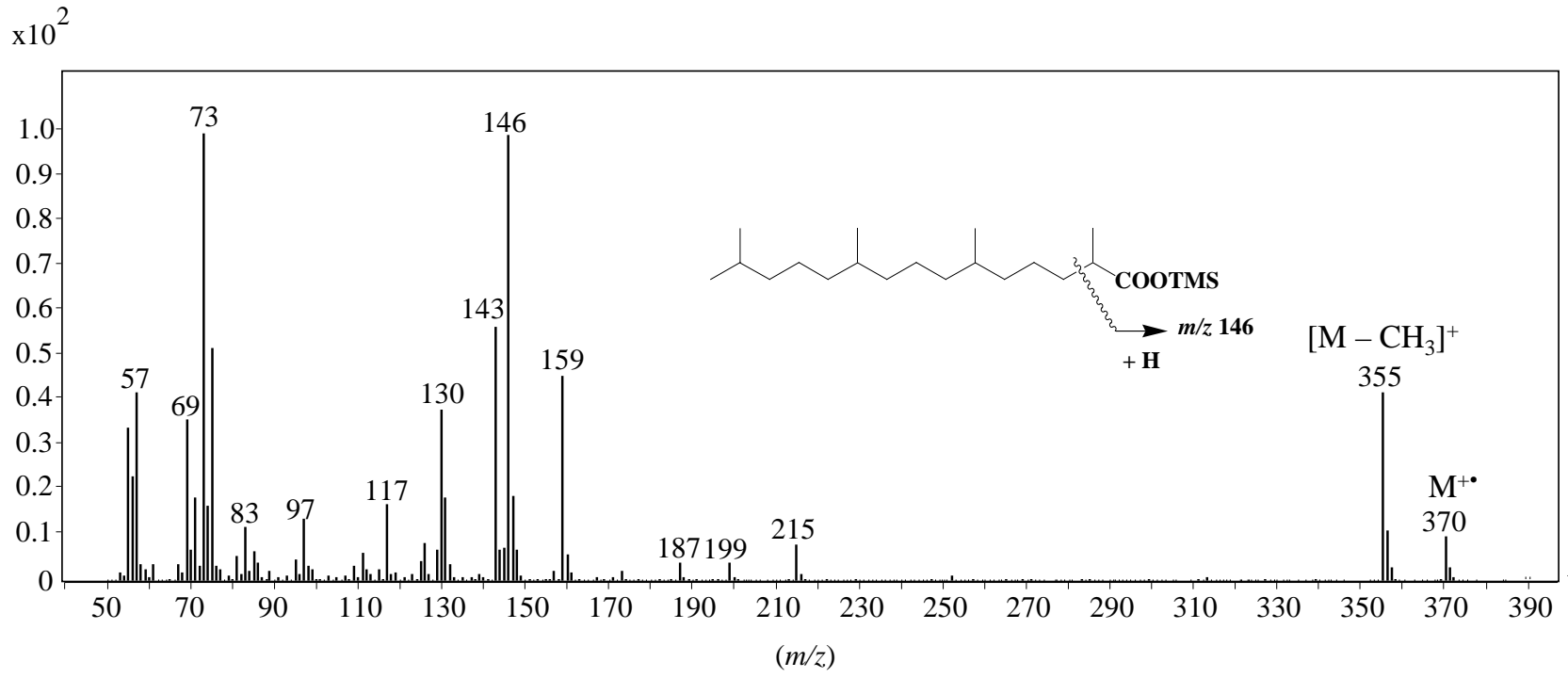

B

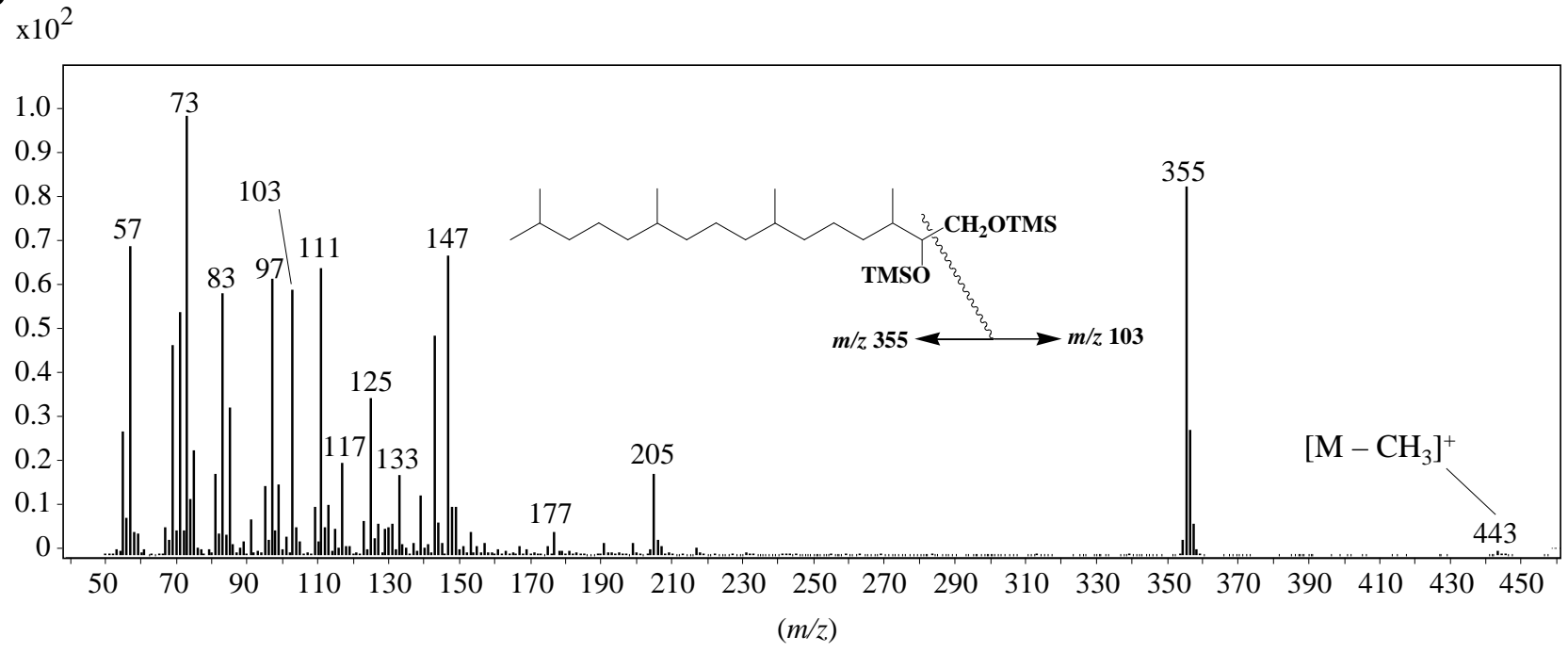


A

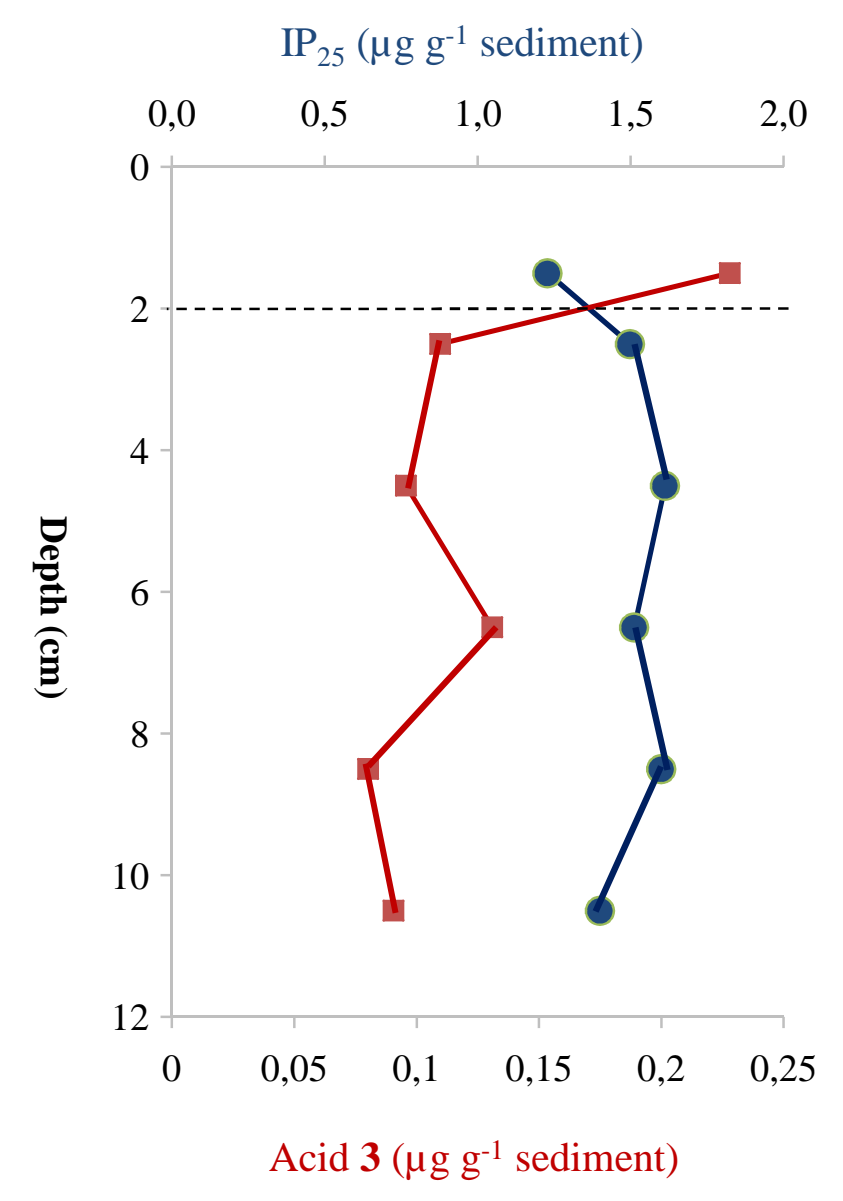

B

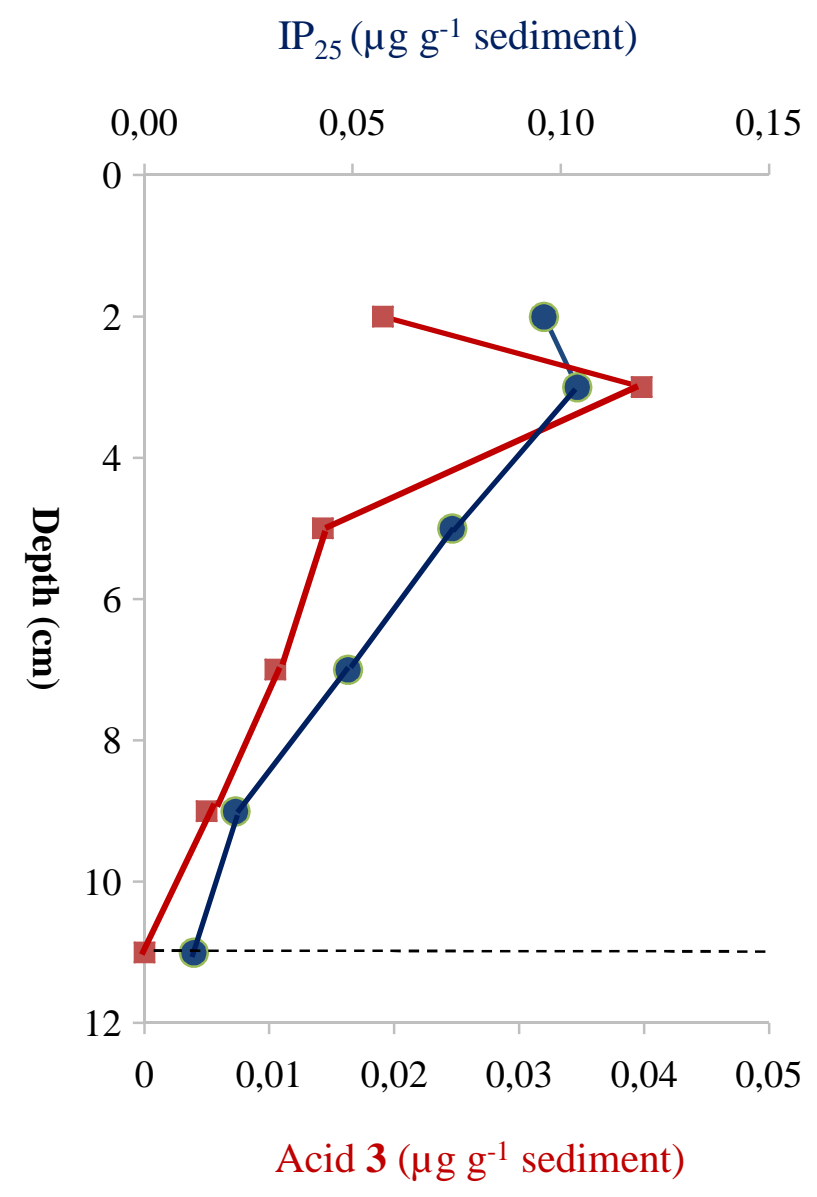




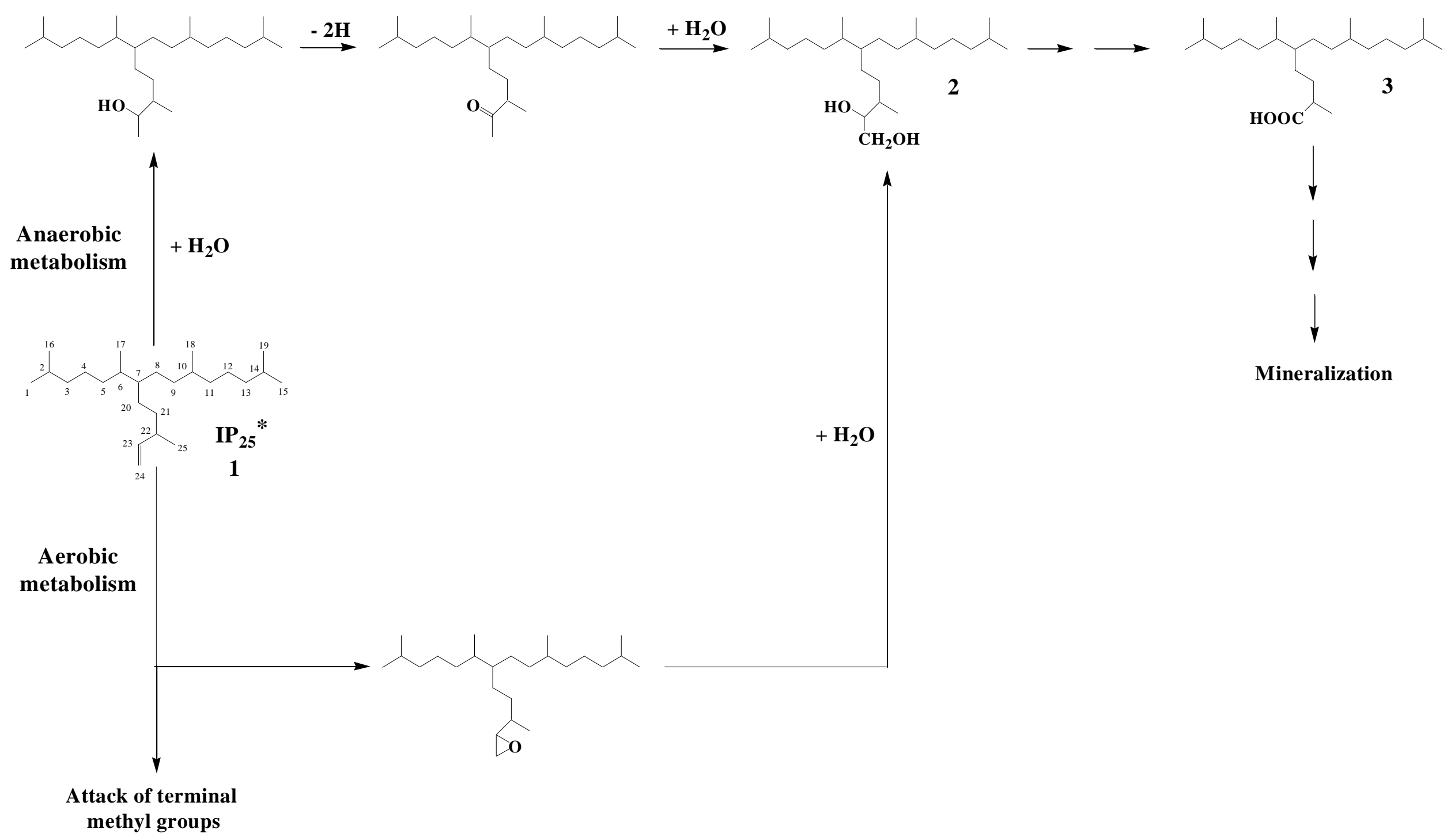



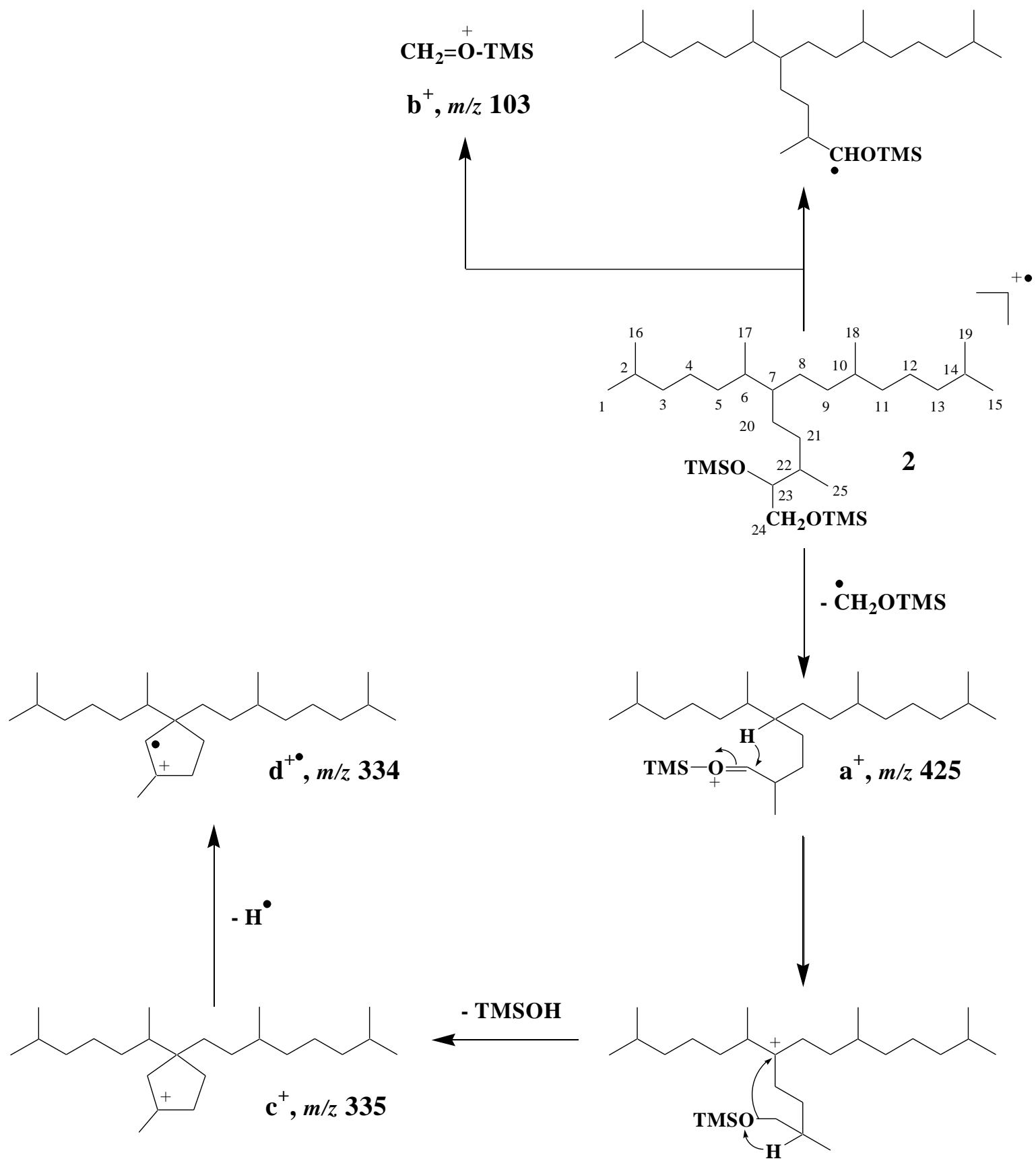


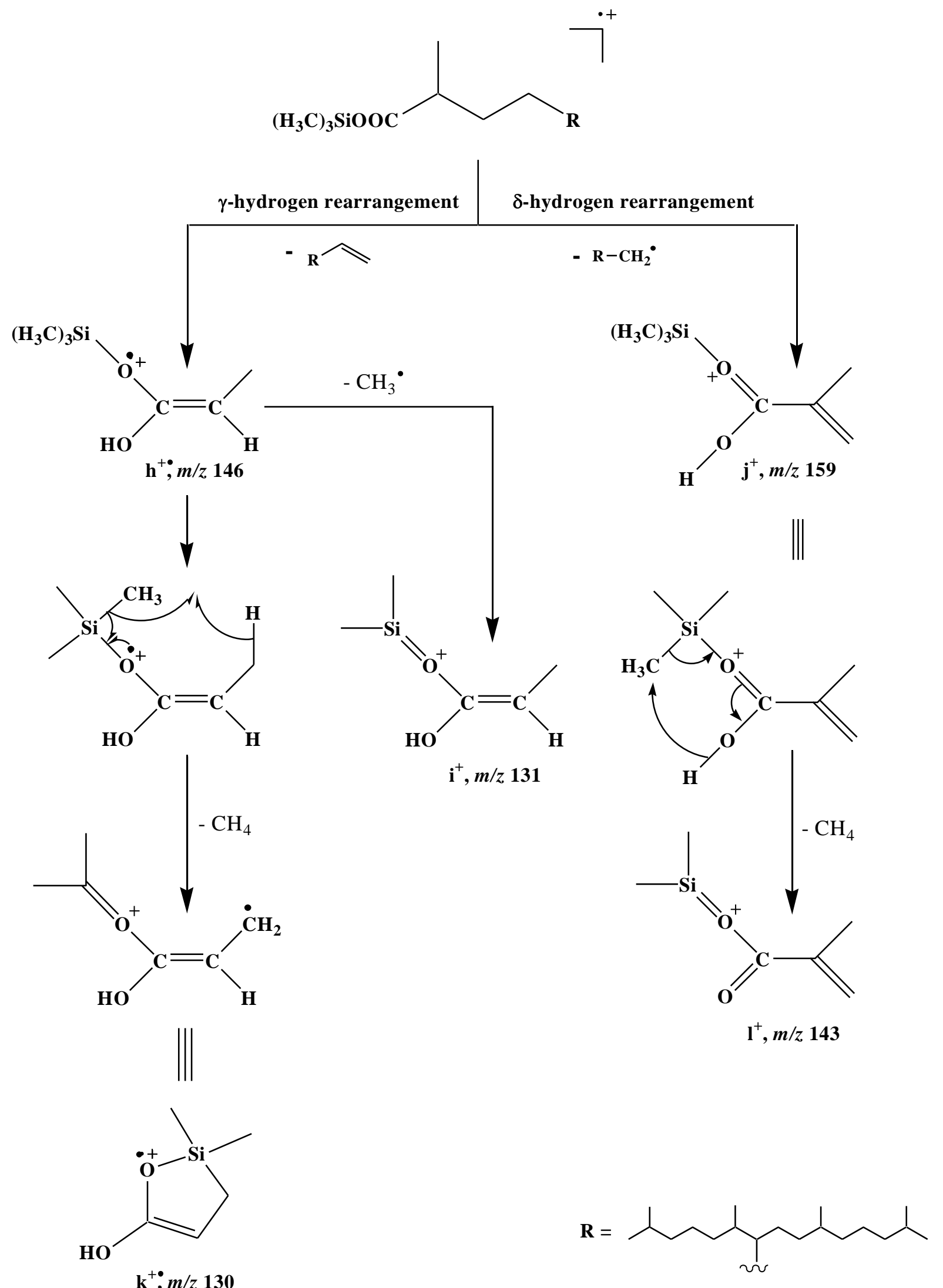


Table 1. CID analyses of labelled and unlabelled fragment ions.

\begin{tabular}{|c|c|c|c|}
\hline Code & $m / z$ & $\begin{array}{l}\text { Collision } \\
\text { energy } \\
(\mathrm{eV})\end{array}$ & Product ions \\
\hline $\mathbf{a}^{+}$ & 425 & 2 & $\begin{array}{l}425(100), 335(8), 334(13), 279(10), 223(12), 209(37), 195(24), \\
181(25), 167(20), 155(17), 141(23), 125(95), 111(99), 97(76), \\
85(61), 71(61)\end{array}$ \\
\hline $\mathbf{c}^{+}$ & 335 & 2 & $\begin{array}{l}335(73), 334(100), 263(12), 249(23), 209(28), 137(69), 124(41), \\
111(41), 110(27), 97(44), 57(37)\end{array}$ \\
\hline $\mathbf{e}^{+}$ & 355 & 2 & $\begin{array}{l}355(100), 209(4), 199(2), 181(3), 139(20), 125(43), 113(11), \\
111(77), 103(11), 99(18), 97(59), 85(34), 83(42), 71(42), 57(35)\end{array}$ \\
\hline $\mathbf{h}^{+\bullet}$ & 146 & 5 & 146(7), 131(56), 130(100), 129(12), 86(66), 75(36), 73(43), 56(61) \\
\hline $\mathbf{h}^{+\bullet}$ & $155^{\mathrm{a}}$ & 0 & 155(82), 137(14), 136(100), 92(16), 82(6), 81(11), 56(17) \\
\hline $\mathbf{h}^{+\bullet}$ & $155^{\mathrm{a}}$ & 5 & $\begin{array}{l}\text { 155(11), 137(15), 136(100), 135(10), 92(61), 82(21), 81(32), } \\
56(57)\end{array}$ \\
\hline $\mathbf{j}^{+}$ & 159 & 5 & 159(12), 143(100), 99(4), 73(20), 69(75) \\
\hline $\mathbf{j}^{+}$ & $168^{\mathrm{a}}$ & 5 & 168(8), 149(100), 97(5), 82(13), 69(76) \\
\hline $\mathbf{m}^{+}$ & 327 & 10 & $\begin{array}{l}327(48), 311(57), 237(43), 219(27), 163(41), 137(23), 125(39), 111 \\
(62), 97(67), 83(82), 73(100)\end{array}$ \\
\hline $\mathbf{m}^{+}$ & $336^{\mathrm{a}}$ & 10 & $\begin{array}{l}336(43), 317(69), 237(100), 219(37), 163(29), 149(14), 111(40), 97 \\
(84), 82(72)\end{array}$ \\
\hline
\end{tabular}

${ }^{\mathrm{a}}$ Fragments with perdeuterated TMS 
Table 2. High-accuracy mass spectral data for ions $\mathbf{a}^{+}-\mathbf{n}^{+}$

\begin{tabular}{|c|c|c|c|c|}
\hline Code & Formula & $m / z$ observed & $\mathrm{m} / z$ calculated & $\Delta(\mathrm{ppm})$ \\
\hline $\mathbf{b}^{+}$ & $\mathrm{C}_{4} \mathrm{H}_{11} \mathrm{OSi}$ & 103.0571 & 103.0574 & -2.9 \\
\hline $\mathbf{k}^{+\bullet}$ & $\mathrm{C}_{5} \mathrm{H}_{10} \mathrm{O}_{2} \mathrm{Si}$ & 130.0440 & 130.0445 & -3.8 \\
\hline $\mathbf{i}^{+}$ & $\mathrm{C}_{5} \mathrm{H}_{11} \mathrm{O}_{2} \mathrm{Si}$ & 131.0511 & 131.0523 & -9.1 \\
\hline $\mathbf{k}^{+\bullet}$ & $\mathrm{C}_{5} \mathrm{H}_{4} \mathrm{D}_{6} \mathrm{O}_{2} \mathrm{Si}$ & 136.0830 & 136.0821 & +6.6 \\
\hline $1^{+}$ & $\mathrm{C}_{6} \mathrm{H}_{11} \mathrm{O}_{2} \mathrm{Si}$ & 143.0519 & 143.0523 & -2.8 \\
\hline $\mathbf{h}^{+\bullet}$ & $\mathrm{C}_{6} \mathrm{H}_{14} \mathrm{O}_{2} \mathrm{Si}$ & 146.0755 & 146.0758 & -3.4 \\
\hline $1^{+}$ & $\mathrm{C}_{6} \mathrm{H}_{5} \mathrm{D}_{6} \mathrm{O}_{2} \mathrm{Si}$ & 149.0907 & 149.0899 & +5.4 \\
\hline $\mathbf{h}^{+\bullet}$ & $\mathrm{C}_{6} \mathrm{H}_{5} \mathrm{D}_{9} \mathrm{O}_{2} \mathrm{Si}$ & 155.1330 & 155.1322 & +5.2 \\
\hline $\mathbf{j}^{+}$ & $\mathrm{C}_{7} \mathrm{H}_{15} \mathrm{O}_{2} \mathrm{Si}$ & 159.0832 & 159.0836 & -2.5 \\
\hline $\mathbf{j}^{+}$ & $\mathrm{C}_{7} \mathrm{H}_{6} \mathrm{D}_{9} \mathrm{O}_{2} \mathrm{Si}$ & 168.1407 & 168.1398 & +5.3 \\
\hline $\mathbf{n}^{+}$ & $\mathrm{C}_{16} \mathrm{H}_{29} \mathrm{O}$ & 237.2207 & 237.2218 & -4.6 \\
\hline $\mathbf{m}^{+}$ & $\mathrm{C}_{19} \mathrm{H}_{39} \mathrm{O}_{2} \mathrm{Si}$ & 327.2714 & 327.2719 & -2.4 \\
\hline$d^{+\bullet}$ & $\mathrm{C}_{24} \mathrm{H}_{46}$ & 334.3593 & 334.3595 & -0.6 \\
\hline $\mathbf{c}^{+}$ & $\mathrm{C}_{24} \mathrm{H}_{47}$ & 335.3667 & 335.3673 & -1.8 \\
\hline $\mathbf{m}^{+}$ & $\mathrm{C}_{19} \mathrm{H}_{30} \mathrm{D}_{9} \mathrm{O}_{2} \mathrm{Si}$ & 336.3290 & 336.3279 & +3.3 \\
\hline $\mathbf{g}^{+}$ & $\mathrm{C}_{26} \mathrm{H}_{53} \mathrm{O}_{2} \mathrm{Si}$ & 425.3802 & 425.3810 & -1.9 \\
\hline $\mathbf{a}^{+}$ & $\mathrm{C}_{27} \mathrm{H}_{57} \mathrm{OSi}$ & 425.4172 & 425.4174 & -0.5 \\
\hline $\mathbf{f}^{+\bullet}$ & $\mathrm{C}_{27} \mathrm{H}_{56} \mathrm{O}_{2} \mathrm{Si}$ & 440.4035 & 440.4045 & -2.3 \\
\hline
\end{tabular}


Table 3. Concentration and proportion of $\mathrm{IP}_{25}$ metabolites in the sediments investigated.

\begin{tabular}{|c|c|c|c|c|}
\hline \multicolumn{5}{|c|}{ STN 4 (Barrow Strait) } \\
\hline $1-2 \mathrm{~cm}$ & 1.229 & 0.933 & 0.229 & 18.6 \\
\hline $2-3 \mathrm{~cm}$ & 1.498 & 1.185 & 0.110 & 7.3 \\
\hline $4-5 \mathrm{~cm}$ & 1.613 & 2.260 & 0.096 & 6.0 \\
\hline $8-9 \mathrm{~cm}$ & 1.542 & 0.691 & 0.080 & 5.2 \\
\hline $9-10 \mathrm{~cm}$ & 1.234 & 4.388 & 0.091 & 7.4 \\
\hline \multicolumn{5}{|c|}{ STN 308 (Western Amundsen } \\
\hline $1-2 \mathrm{~cm}$ & 0.096 & $\mathrm{nd}^{*}$ & 0.019 & 19.8 \\
\hline $2-3 \mathrm{~cm}$ & 0.104 & nd & 0.039 & 37.5 \\
\hline
\end{tabular}

$*<$ LOD 